\title{
MULTIKULTURAL DAN PENDIDIKAN KARAKTER KESENIAN DIDONG PADA MASYRAKAT GAYO KABUPATEN ACEH TENGAH
}

\author{
Putra afriadi \\ Pascasarjana Universitas Negeri Semarang \\ Putraafriadi12@gmail.com
}

\begin{abstract}
Culture is the result of society's habits, in this case in the form of thoughts, works of art to the form of language. Then the form of the youth survived until now, through the learning process. Therefore, other traditions than found are also created. Thus the form of culture (in this case the art of traditional performances) can be understood as a performing arts activity that contains the value and meaning of thoughts, customs, beliefs, norms, customs to be inherited from generation to generation. Especially Didong performing arts, as a result of Gayo culture, Didong played a big role in unifying ethnic Gayo who has a variety of opinions about moral and aesthetic values about the existing culture. Of course as a medium of learning, especially in the realm of character education with value approach, Didong is the right art. With the concept put forward by Douglas P. Superka. Almost all regional arts have a high essence, which can be used as an art medium in character education. It all depends on what, who, and how it is applied. In multicultural perspectives, Didong is a means to unite all ethnic groups in Gayo area, not vice versa. Didong is not claimed as possession of any area but joint ownership. Must be able to mengyukan aesthetic understanding of what is in the show Didong overall, so there is no misunderstanding that can damage the value of art from Didong itself.
\end{abstract}

Key Words: art, character education, values, multiculturalism, Didong.

\begin{abstract}
Abstrak: Kebudayaan tersebut merupakan hasil kebiasaan masyarakat, dalam hal ini berupa pemikiranpemikiran, karya seni sampai pada bentuk bahasa. Kemudian bentuk dari kebudaan itu bertahan sampai sekarang, melalui proses pembelajaran. Oleh karena itu, tradisi selain di temukan juga diciptakan. Dengan demikian bentuk kebudayaan (dalam hal ini seni pertunjukan tradisional) dapat dipahami sebagai kegiatan seni pertunjukan yang memuat nilai dan makna pemikiran, kebiasaan, kepercayaan, norma, adat istiadat untuk diwariskan dari generasi ke generasi. Khususnya seni pertunjukan Didong, sebagai hasil dari kebudayaan Gayo, Didong berperan besar dalam mempersatukan etnis Gayo yang memiliki berbagai macam pendapat mengenai nilai-nilai moral dan estetika tentang budaya yang ada. Tentu saja sebagai media pembelajaran, khususnya dalam ranah pendidikan karakter dengan pendekatan nilai, Didong merupakan kesenian yang tepat. Dengan konsep yang dikemukakan oleh Douglas P. Superka. Hampir semua kesenian daerah memiliki esensi yang tinggi, yang dapat digunakan sebagai media seni dalam pendidikan karakter. Itu semua bergantung pada apa, siapa, dan bagaiman hal tersebut diterapkan. Dalam persepektif multikulturalisme, Didong merupakan sebuah sarana untuk menyatukan seluruh etnis yang ada di daerah Gayo, bukan sebaliknya. Didong tidak diklaim sebagai kepemilikan setiap daerah melainkan kepemilikan bersama. Harus dapat meyatukan pemahaman estetika tentang apa yang ada dalam pertunjukan Didong secara keseluruhan, sehingga tidak terjadi kesalah pahaman yang dapat merusak nilai seni dari Didong itu sendiri.
\end{abstract}

Kata kunci: kesenian, pendidikan karakter, nilai, multikultural, Didong.

\section{PENDAHULUAN}

Masyarakat memiliki kebudayaan yang berjalan beriringan dengan perubahan dari massa ke masaa, yang kemudian bergerak dari satu waktu ke waktu yang lain, dan akhirnya berubah menjadi sebuah peradaban. Peradaban adalah suatu kebudayaan yang teruji atau bertahan dari waktu ke waktu karena pengaruh masyakat itu sendiri.
Kemudian di dalam sebuah peradaban ataupun budaya terdapat bentuk dari sistem masyarakat itu sendiri, seperti interaksi sosial, seni dan religius. Pada akhirnya akan membentuk karakter suatu bangsa. Cara hidup manusia dengan berbagai macam sistem tindakan dijadikan sebagai objek penelitian dan analisis oleh ilmu antropologi sehingga aspek belajar merupakan aspek pokok. Itulah 
sebabnya dalam hal memberi pembatasan terhadap konsep "kebudayaan" atau culture, ilmu antropologi berbeda dengan ilmu yang lain.kalau dalam bahasa sehari-hari "kebudayaan" dibatasi hanya pada hal-hal yang indah (seperti candi, tari-tarian, seni rupa, seni suara, kesustraan dan filsafat. Menurut ilmu antropologi, "kebudayaan" adalah keseluruhan sistem gagasan, tindakan dan hasil karya manusia dalam kehidupan masyarakat yang dijadikan milik diri manusia dengan belajar (koent- jaraningrat, 2009:144). Artinya adalah kebudayaan tersebut merupakan hasil kebiasaan masyarakat, dalam hal ini berupa pemikiran-pemikiran, karya seni sampai pada bentuk bahasa. Kemudian bentuk dari kebudaan itu bertahan sampai sekarang, melalui proses pembelajaran. Oleh karena itu, tradisi selain di temukan juga diciptakan. Dengan demikian bentuk kebudayaan (dalam hal ini seni pertunjukan tradisional) dapat dipahami sebagai kegiatan seni pertunjukan yang memuat nilai dan makna pemikiran, kebiasaan, kepercayaan, norma, adat istiadat untuk diwariskan dari generasi ke generasi. Begitu pula msyarakat Gayo.

Masyarakat Gayo hidup dalam komuniti kecil yang disebut kampong. Setiap kampong kampong dikepalai oleh seorang gecik. Kumpulan beberapa kampong disebut kemukiman, yang dipimpin oleh mukim. System pemerintahan tradisional berupa unsur kepemimpinan yang disebut sarak opat, terdiri dari reje (raja), petue (petua), imem (imam), dan rayat (rakyat). Pada masa sekarang sebuah kemukiman merupakan bagian dari kecamatan, dengan unsur-unsur kepemimpinan terdiri atas: gecik, wakil gecik, imem, dan cerdik pandai yang mewakili rakyat. Sebuah kampong biasanya dihuni oleh beberapa kelompok belah (klan). Anggota suatu belah merasa berasal dari satu nenek moyang. Masih saling mengenal, dan mengembangkan hubungan tetap dalam berbagai upacara adat. Garis keturunan ditarik berdasarkan prinsip patrilineal. System perkawinan yang berlaku berdasarkan tradisi adalah eksogami belah, dengan adat menetap sesudah menikah yang patrilokal (juelen) atau matrilokal (angkap). Kelompok kekerabatan terkecil disebut sara ine (keluarga inti). Kesatuan beberapa keluarga inti disebut sara dapur. Pada masa lalu beberapa sara dapur tinggal bersama dalam sebuah rumah panjang, sehingga disebut sara umah. Beberapa buah rumah panjang bergabung ke dalam satu belah (klan). Pada masa sekarang banyak keluarga inti yang mendiami rumah sendiri. Pada masa lau orang Gayo terutama mengembangkan mata pencaharian bertani di sawah dan beternak, dengan adat istiadat mata pencaharian yang rumit. Selain itu ada penduduk yang berkebun, menangkap ikan, dan meramu hasil hutan. Mereka juga mengembangkan kerajinan membuat keramik, menganyam, dan menenun. Kini pencaharian dominan adalah berkebun, terutama tanaman kopi. Kerajinan membuat keramik dan anyaman pernah terancam punah, namun dengan dijadikannya daerah ini sebagai daerah salah satu tujuan wisata di Aceh, kerajinan keramik mulai berkembang lagi. Kerajinan lain yang juga banyak mendapat perhatian adalah kerajinan membuat sulaman kerawang dengan motif yang khas (Darmawan, 2010).

Bahasa Gayo merupakan salah satu bahasa dinusantara bagian bahasa Melayu Polinesia, dan dikelompokkan dalam bagian Austronesia. Keberadaan bahasa ini sama dengan keberadaan orang Gayo (urang Gayo). Perkembangan bahasa Gayo tidak terlepas dari persebaran orang Gayo, menjadi beberapa kelompok, yaitu Gayo lut (Kabupaten Aceh Tengah dan Bener Meriah), Gayo Deret yang mendominasi di daerah Isaq Linge dan sekitarnya (masih merupakan bagian wilayah kabupaten Aceh Tengah), Gayo lukup/serbejadi (Kabupaten Aceh Timur), Gayo Kalul (Aceh Tamiang), dan Gayo Blang (Kabupaten Gayo Lues dan Kabupaten Aceh Tenggara) (Algayoni,2015).

Gayo merupakan salah satu wilayah kebudayaan yang berada di Provinsi Aceh. Sebagai suatu wilayah kebudayaan tentu memiliki warisan budaya yang sampai saat ini masih berkembang di dalamnya. Ketika kita mendekati masyarakatnya, di Gayo perwujudan ekspresi berkesenian masyarakatnya begitu besar. Masyarakat Gayo kiranya tidaklah demikian kaya dengan variasi perwujudan artistik berupa hasil kebudayaan material, meskipun mereka 
mengenal seni arsitektur, ukir, relief, hias, perhiasan. Tampaknya mereka lebih banyak memiliki dan menyenangi berupa kesusastraan seperti puisi, teka-teki, perumpamaan, nyanyian, deklamasi (recitation), legenda dan sebagainya. Oleh karena itu rupanya unsur-unsur kesenian dari luar seperti sa'er, drama, nyanyian, lebih cepat masuknya. Salah satu kesenian yang paling populer di masyarakat Gayo adalah Didong.

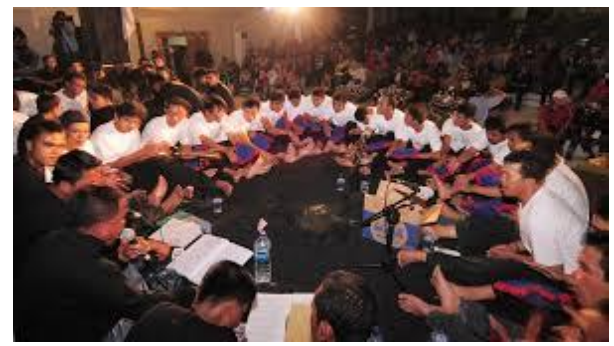

Gambar 1 : Seni pertunjukan tradisional Didong (sumber : www.lintasGayo.com)

Didong juga bisa dinyatakan sebagai salah satu varian dari "nyanyian rakyat" (folksong). Didong memiliki prinsip lisan yang berperan penyampaian pesan moral pada msyarakat luas (Melalatoa,2001:11). Dengan rumusan sederhana, kesenian Didong dapat dinyatakan sebagai konfigurasi ekspresi seni sastra, seni suara, dan seni tari. Pergelaran Didong ini biasa diadakan di tempat atau ruang khusus sebagai pentas, misalnya tempo dulu di ruang luas rumah panggung (umah sara); di atas panggung buatan pada ruang terbuka, misal di halaman, lapangan dan lainlain. Pentas ini tentunya dilengkapi dengan sarana penerangan, mulai dari yang sederhana seperti api unggun, petromak atau lampu listrik pada masa-masa terakhir ini. Keseluruhan pemain dilengkapi dengan bantal kecil (kampas) sebagai alas tepukan-tepukan tangan yang menjadi ritme bagi melodi dalam kesenian ini. Anggota satu kelop terkadang memakai baju seragam yang biasa disebut sebagai baju-kelop, sedangkan aktor utamanya biasanya memakai atribut tambahan berupa syal yang dililitkan di leher dan ada yang memakai kopiah. Di antara sejumlah unsur seni bertutur yang terangkum dalam seni Didong adalah: Kekitiken/Ure-ure (seni berteka-teki). Yaitu seni dalam berteka-teki yang biasanya dilakukan oleh anak-anak menjelang tidur. Dari segi bahasa dan kalimat yang digunakan dalam teka-teki ini lebih mementingkan tata bunyi dan irama dengan pola persajakan a-b a-b.

Didong itu sendiri memiliki bentuk pertunjukan yang lain yang dinamakan Didong Jalu. Biasanya Didong Jalu dimainkan oleh dari masingmasing kelop berjumlah sekitar 30 pemain. Mereka terbagi atas dua kategori utama, yaitu ceh dan penunung atau penyur (pengirin g) (Melalatoa,2001:11). Seorang yang bisa disebut ceh harus memenuhi syarat. Modal utamanya adalah suara merdu (ling temas). Suara merdu saja tidak cukup, ia pun harus punya kemampuan menciptakan lirik atau puisi (kekata) sendiri, yang akan ditembangkan dengan model melodi ciptaan sendiri tadi. Ia harus punya pengetahuan yang luas perihal latar belakang adat istiadat (edet) masyarakatnya dengan segala perkembangan atau perubahan yang terjadi dan juga pengetahuan tentang lingkungan lain yang lebih luas. Pengetahuan luas ini harus berimbang dengan kekayaan perbendaharaan kata, ungkapan, simbol-simbol pikiran, sehingga lahirlah lirik-lirik indah dengan bobot pesan yang dalam, tajam, aktual, tapi juga ajek. Karya dengan bobotnya yang ajek itu berarti sebuah lirik menyimpan pandangan yang menjadi bahan renungan bahkan menjadi acuan dalam kehidupan masyarakatnya. Berdasarkan kenyataan tersebut penulis akan membahas suatu permasalahan yang terjadi dimasyarakat terkait seni perunjukan pertunjukan tadisioanal masyarakat Gayo, tepatnya di Kabupaten Aceh Tengah yang bernama Didong. Didong merupakan seni tradisi pertunjukan yang berasal dari masyarakat Gayo, dimana Didong menjadi sarana untuk menyampaikan suatu ekspresi masyarakat akan kehidupan keseharian, berisikan pesan kepada generasi muda yang akan datang. Berdasarkan peryataan di atas ada beberapa hal yang menjadi topik pembahasan yaitu, (1). Bagaimakah pendidikan karakter pada kesenian Didong dalam kehidupan masyarakat Gayo?, dan (2). bagaimanakah kesenian Didong dalam konteks multikulturalisme masyarakat Gayo?

Pendidikan Karakter (Pendekatan Nilai Dan Karakter) 
Thomas Lickona di dalam bukunya Educating for Character: How Our Schools Can Teach Respect and Responsibility mencontohkan krisis moral yang terjadi, dalam hal ini di Amerika, berawal dari merebaknya sifat individualisme yang menekankan pada kepentingan pribadi dan telah melahirkan sikap egoisme sebagai gaya hidup (Lickona, 2013:18). Sifat individualisme cenderung egoisme tersebut kemudian berkembang menjadi banyak penyelewengan nilai dan karakter, dalam contoh ini Lickona menampilkan 10 indikasi, misalnya kekerasan dan tindakan anarki, pencurian, tindakan curang, pengabaian terhadap aturan yang berlaku, tawuran antar siswa, ketidak toleran, penggunaan bahasa yang tidak baik, kematangan seksual yang terlalu dini dan penyimpangannya, dan sikap perusakan diri.

Pada tahun 1987, kemunduran moral semacam ini telah dirasakan oleh banyak negara yang tergabung dalam sebuah konferensi mengenai pendidikan moral. Sebagai sebuah kesimpulan, dalam konferensi tersebut, kelumpuhan di bidang nilai tersebut cenderung berfokus pada masalah yang terjadi beberapa tahun silam mengenai pengajaran nilai. Artinya, sistem pendidikan harus kembali dijadikan media yang dapat menolong keterpurukan tersebut.

Dalam bahasa yang sama, Asep Saeful Hidayat mengatakan bahwa mutu proses pembelajaran menjadi obyek tuduhan pertama terhadap rendahnya karakter peserta didik. Para pakar perancang pembelajaran menempatkan langkah analisis karakteristik siswa sebelum langkah pemilihan dan pengembangan strategi pembelajaran. Hal ini mengisyaratkan bahwa teori pembelajaran apapun yang dikembangkan dan strategi maupun pendekatan apapun yang dipilih untuk keperluan pembelajaran haruslah berpijak pada nilai-nilai karakter (Saeful Hidayat, 2012: 9).

Dalam hal ini, melalui 11 Principles of Character Education Thomas Lickona mengajukan prinsip-prinsip dalam pendidikan karakter yang salah satunya adalah penggunakan pendekatan komprehensif, intensional dan proaktif untuk membangun karakter. Yaitu sebagai berikut:
1. Menjunjung Nilai-nilai Luhur

2. Karakter Mencakup Pemahaman, Penghayatan, dan Pengamalan

3. Menggunakan Pendekatan Holistik

4. Membangun Komunitas Peduli

5. Menyediakan Kesempatan bagi Peserta Didik untuk Mengaktualisasikan Moral

6. Merancang Kurikulum Akademik yang Bermakna dan Menantang

7. Menumbuhkan Motivasi-Diri Peserta Didik

8. Menggalang Seluruh Staf Sekolah sebagai Komunitas Belajar

9. Memupuk Kepemimpinan Kolegial

10. Menggalang Keluarga dan Masyarakat sebagai Mitra

11. Memantau Budaya dan Iklim Sekolah Dalam penjelasannya terkait maksud pendekatan komprehensif, intensional dan proaktif di sini, lebih lanjut Lickona menulis:

"Schools committed to character development look at themselves through a character lens to assess how virtually everything that goes on in school affects the character of students. A comprehensive approach uses all aspects of schooling as opportunities for character development. This includes the formal academic curriculum and extracurricular activities, as well as what is sometimes called the hidden or informal curriculum (e.g., how school procedures reflect core values, how adults model good character, how the instructional process respects students, how student diversity is addressed, and how the discipline policy encourages student reflection and growth". (Lickona, 2010).

Berbeda dengan Thomas Lickona, Superka dengan lebih detail memberikan 5 pendekatan yang dapat digunakan dalam pendidikan nilai dan karakter. Pendekatan tersebut adalah pendekatan penanaman nilai (inculcation approach), pendekatan perkembangan moral kognitif (cognitive moral development approach), pendekatan analisis nilai (values analysis approach), pendekatan klarifikasi nilai (values clarification approach), dan pendekatan 
pembelajaran berbuat (action learning approach). (Dalmeri, 2014: 278).

Masing-masing pendekatan yang dikemukakan oleh Douglas P. Superka tersebut dapat dijelaskan sebagai berikut:

\section{a. Pendekatan Penanaman Nilai}

\section{(Inculcation Approach)}

Pendekatan penanaman nilai (inculcation approach) merupakan pendekatan yang memberi penekanan pada penanaman nilai-nilai sosial dalam peserta didik. Tujuan dari pendekatan penanaman nilai adalah untuk menanamkan nilai-nilai tertentu yang diinginkan. Menurut pendekatan ini, nilai-nilai dipandang sebagai standar atau aturan perilaku yang bersumber dari masyarakat dan budaya. Menilai dianggap sebagai identifikasi proses dan sosialisasi dimana seseorang, kadang-kadang secara tidak sadar, mengambil standar atau normanorma dari orang, kelompok, atau masyarakat lain dan menggabungkan mereka ke dalam sistem nilai sendiri (Superka, 1976: 9).

\section{b. Pendekatan Perkembangan Moral}

\section{Kognitif (Cognitive Moral Development Approach)}

Pendekatan ini seringkali disebut dengan pendekatan perkembangan kognitif karena karakteristiknya memberikan penekanan pada aspek kognitif dan perkembangannya (Dalmeri, 2014: 278). Pendekatan ini merupakan upaya untuk merangsang siswa untuk mengembangkan pola penalaran moral yang lebih kompleks melalui tahap berturut-turut dan berurutan (Superka, 1976: 31). Tahap berurutan disini dimkasudkan sebagai tahapan perkembangan tingkat berpikir dalam membuat pertimbangan moral, dari tingkat rendah menuju tingkatan yang lebih tinggi.

\section{c. Pendekatan Analisis Nilai (Values Analysis Approach)}

Pendekatan analisis nilai (values analysis approach) memberikan penekanan pada perkembangan kemampuan peserta didik untuk berpikir logis, dengan cara menganalisis masalah yang berhubungan dengan nilai- nilai sosial. Jika dibandingkan dengan pendekatan perkembangan kognitif, salah satu perbedaan diantara keduanya adalah pendekatan analisis nilai lebih menekankan pada pembahasan masalah-masalah yang memuat nilai-nilai sosial. Adapun pendekatan perkembangan kognitif memberi penekanan pada dilema moral yang bersifat perseorangan (Dalmeri, 2014: 279). Berbeda dengan pendekatan perkembangan moral, analisis nilai berkonsentrasi terutama pada isu-isu nilai sosial daripada dilema moral pribadi (Superka, 1976: 36).

\section{d. Pendekatan Klarifikasi Nilai (Values Clarification Approach)}

Pendekatan klarifikasi nilai (values clarification approach) memberi penekanan pada usaha untuk membantu peserta didik dalam mengkaji perasaan dan perbuatannya sendiri, serta meningkatkan kesadaran mereka tentang nilai-nilai mereka sendiri dengan cara berpikir secara rasional dan juga menggunakan kesadaran emosional secara bersama-sama (Superka, 1976: 104).

\section{e. Pendekatan Pembelajaran Berbuat \\ (Action Learning Approach)}

Pendekatan pembelajaran berbuat (action learning approach) memberi penekanan pada usaha memberikan kesempatan kepada peserta didik untuk melakukan perbuatan-perbuatan moral, baik secara perseorangan maupun secara bersamasama dalam suatu kelompok (Superka, 1976: 177).

\section{Multikulturalisme}

Multikulturalisme adalah sepe- rangkat ide atau gagasan yang menghasilkan aliran yang berpandang bahwa terdapat variasi budaya dalam masyarakat, yang terjadi adalah adanya kesetaraan budaya, sehingga antara satu entitas budaya dengan budaya lainnya tidaklah berada dalam suasana bertanding untuk memenangkan pertarungan (Syam, 2009:79). Secara antropologis , menurut Demerath dan Mattheis (2012), dalam masyarakat pluralistik, nilai-nilai multikulturalisme yang terwujud dalam kesadaran bersikap dan berperilaku untuk menghargai dan menerima keanekaragaman atau perbedaan budaya ini penting disosialisasikan atau ditanamkan, karena itu dapat menjadi pengikat persatuan dan kesatuan serta kesetaraan dalam menjalankan kehidupan bermasyarakat, berbangsa, dan bernegara secara demokratis, tanpa prasangka, tidak diskriminatif dan menghargai hak asasi (Mukni dalam Mahfud, 2006; lihat juga Banks dan Banks 2010; dalam TRiyanto, 2017). Artinya adalah multikulturalisme menunjukan 
adanya sikap menghargai berbagai macam etnis budaya. Bukan hanya sekedar menunjukan sikap menghargai, tapi juga sebagai pemersatu antar budaya, ras dan bahasa.

Terdapat tiga sentral multikulturalisme yang dipandang sebagai perspektif tentang kehidupan manusia oleh Bhikhu Parekh (2008), yaitu:

1. Manusia secara kultural dilekatkan dalam posisi bahwa mereka tumbuh dan hidup dalam dunia yang terstruktur secara kultural, mengorganisasikan dan hubungan-hubungan social menurut system makna, memposisikan tentang identitas kultural mereka.

2. Kebudayaan-kebudayaan yang berbeda mencerminkan system makna dan jalan pandangan hidup yang baik. Karena masing-masing merelasasikan satu jangkauan terbatas menyangkut kapsitas dan emosi manusia dan menggenggam hanya sebagian dari totalitas eksistensi manusia, masing-masing kebudayaan memerlukan kebudayaan lain untuk memahami dirinya lebih baik, memperluas cakrawala intelektual dan moral, mengembangan imajinasi dan melindunginya terhadap gangguangangguan nyata untuk memutlakkan dirinya.

3. Semua kebudayaan kecuali yang paling primitif secara internal bersifat majemuk dan mencerminkan sebuah percakapan berkelanjutan antara tradisi dan rangkaian gagasan mereka yang berbeda-beda.

Kemudian Parekh

(2008:443)

mengatakan bahwa, apa yang mungkin saya sebut sebagai sebuah perspektif multikultur terdiri dari satu keadaan saling mempengaruhi yang kreatif dari ketiga wawasan yang bersifat komplementer, yakni keterlekatan kultural manusia, keharusan dan keinginan akan keanekaragaman budaya dan dialog antar kebudayaan, dan kemajemukan internal masing-masing budaya. Artinya adalah semua aspek yang meliputi pemikiran masyarakat tentang kebudayaan, baik itu secara moral, dialog antar budaya dan seni, itu menjadi persepektif multikultur dalam kebudayaan yang membuat kita peka terhadap fakta bahwa semua pemikiran kita tentang budaya itu terbatas.

\section{PEMBAHASAN}

\section{Kesenian Didong dan Pendidikan karakter}

Didong yang merupakan perpaduan dari musik, tari, dan sastra memiliki sejumlah hal yang dapat dikaitkan dengan pendidikan karakter. Sudah sejak lama Didong menjadi ciri khas daerah khususnya masyarakat Gayo. Sebagai media maupun sebagai representasi realitas sosial yang telah teruju dari waktu ke waktu, hal ini tentu saja dapat dijadikan pembelajaran yang berharga yang berkaitan dengan pendidikan karakter. Dilihat dari selama proses pra pertunjukan sampai dengan selesai banyak nilai-nilai karakter yang dapat kita ambil, diantaranya adalah nilai religius/kekudusan, penanaman moral, penanaman nilai luhur, adat-istidat, semua hal tersebut ada dalam satu pertunjukan Didong. Berikut merupakan telaah kesenian Didong dengan menggunakan konsep yang dikemukakan oleh Douglas P. Superka :

\section{a. Pendekatan Penanaman Nilai \\ (Inculcation Approach)}

Menurut pendekatan ini, nilai-nilai dipandang sebagai standar atau aturan perilaku yang bersumber dari masyarakat dan budaya. Menilai dianggap sebagai identifikasi proses dan sosialisasi dimana seseorang, kadang-kadang secara tidak sadar, mengambil standar atau norma-norma dari orang, kelompok, atau masyarakat lain dan menggabungkan mereka ke dalam sistem nilai sendiri. Artinya adalah, Didong sebagai media pendidikan karakter merupakan satu nilai yang dipandang standar atas prilaku yang bersumber dari masyarakat dan budaya masyarakat setempat. Hal ini dibuktikan melalui syair-syair lagu yang muat kedalam bahasa daerah setempat.

\section{b. Pendekatan Perkembangan Moral Kognitif (Cognitive Moral Development Approach)}

Pendekatan ini seringkali disebut dengan pendekatan perkembangan kognitif karena karakteristiknya memberikan penekanan pada aspek kognitif dan perkembangannya. Artinya adalah, Didong yang merupakan kesenian yang termasuk kedalam seni tutur, dimana menggunakan bahasa daerah, yang pada kesempatan lain telah dipertunjukan bahwa adanya keterkaitan antara perkembangan kognitif seseorang. Hal tersebut dibuktikan pada salah satu jenis 
pertunjukan Didongyang lain, yaitu Didong Jalu dimana seniman saling beradu syair yang berisi pesan-pesan moral.

\section{c. Pendekatan Analisis Nilai (Values} Analysis Approach)

Jika dibandingkan dengan pendekatan perkembangan kognitif, salah satu perbedaan diantara keduanya adalah pendekatan analisis nilai lebih menekankan pada pembahasan masalah-masalah yang memuat nilai-nilai sosial. Memang sedikit berbeda dari point ke2 tentang nilai, namun pada point ini kesenian Didong sebagai media pendidikan karakter dengan pendekatan nilai telah memiliki kriteria yang cukup, hal ini dibuktikan dari pertunjukannya bahwasannya memiliki banyak nilai-nilai sosial yang dituangkan kedalam syair, menyangkut norma dan adatistiadat.

\section{d. Pendekatan Klarifikasi Nilai (Values Clarification Approach)}

Pendekatan klarifikasi nilai (values clarification approach) memberi penekanan pada usaha untuk membantu peserta didik dalam mengkaji perasaan dan perbuatannya sendiri, serta meningkatkan kesadaran mereka tentang nilai-nilai mereka sendiri dengan cara berpikir secara rasional dan juga menggunakan kesadaran emosional secara bersama-sama. Pada point ini menunjukan bahwa, kesenian memiliki klarifikasi nilai, berkaitan dengan kebudayaan, kebiasaan, dan hal ini telah didiskusikan secara seksama oleh pemain kesenian Didong. Sebagai media pendidikan karakter, kesenian ini termasuk salah satunya, siswa ataupun masyarakat lain bisa menerapkan sistem diskusi, melalui syair Didong, mereka dapat mengklarifikasi nilai kebudayaan yang ada.

\section{e. Pendekatan Pembelajaran Berbuat (Action Learning Approach)}

Pendekatan pembelajaran berbuat (action learning approach) memberi penekanan pada usaha memberikan kesempatan kepada peserta didik untuk melakukan perbuatan-perbuatan moral, baik secara perseorangan maupun secara bersamasama dalam suatu kelompok. Hal ini berkaitan dengan proses sebelum pertunjukan, dimana semua peserta, termasuk peserta didik ataupun masyarakat, harus melakukan sebuah proses untuk melakukan pertunjukan kesenian Didong. Pada proses ini mereka akan belajar saling menghargai sesama, agar esensi yang terkandung di dalam kesenian tersebut tidak berkurang, walaupun telah dibuat sekreatif mungkin.

\section{Kesenian Didong Dalam Konteks Multikulturalisme}

Masyarakat yang multikulturalisme tidak terikat oleh doktrin apapun dan visi hidup yang baik dan mempertanyakan seberapa besar keanegaragaman itu, karena dalam konteks pespektif multikulturalisme hal tersebut akan membuat kita terbatasi dengan aturan-aturan yang dibuat oleh setiap kelompok. Masyarakat Gayo sendiri memiliki beberapa etnis yaitu alas, deret dan loet. Masing-masing dari etnis tersebut memiliki seninya masing-masing, namun hanya ada satu seni yang dapat merangkul dan menyimbolkan kepemilikan dari seluruh etnis yaitu Didong. Didong bukan milik dari Gayo alas, deret maupun loet tetapi milik semua etnis Gayo. Dalam persepektif multikulturalisme, Didong merupakan sebuah sarana untuk menyatukan seluruh etnis yang ada di daerah Gayo.

Manusia secara kultural dilekatkan dalam posisi bahwa mereka tumbuh dan hidup dalam dunia yang terstruktur secara kultural, mengorganisasikan dan hubungan-hubungan social menurut system makna, memposisikan tentang identitas kultural mereka (Parekh, 2008:440). Dalam hal ini Didong merupakan hasil dari kebudayaan yang dibuat sedemikian rupa yang memiliki hubungan-hubungan social dengan masyarakat Gayo secara umum, merupakan identitas kultural masyarakat Gayo.

Kebudayaan-kebudayaan yang berbeda mencerminkan system makna dan jalan pandangan hidup yang baik. Karena masingmasing merelasasikan satu jangkauan terbatas menyangkut kapasitas dan emosi manusia dan menggenggam hanya sebagian dari totalitas eksistensi manusia, masing-masing kebudayaan memerlukan kebudayaan lain untuk memahami dirinya lebih baik, memperluas cakrawala intelektual dan moral, mengembangan imajinasi dan melindunginya terhadap gangguan-gangguan nyata untuk memutlakkan dirinya (Parekh, 2008:441). Perbedaan etnis mencerminkan system makna dan pandangan yang baik. Masing-masing memiliki intensitas budaya yang berbeda- 
beda, cara pandang yang berbeda-beda. Setiap pertunjukan dari etnis yang ada di daerah Gayo menggunakan caranya tersendiri, terutama pada bagian lirik lagu yang digunakan, Gayo alas akan membuat lirik sesuai dengan bahasa mereka, sedangkan Gayo deret juga membuat lirik sesuai dengan bahasa sehari-hari yang mereka gunakan, begitu juga dengan etnis Gayo yang lain. Setiap etnis saling mempengaruhi, sehingga menjadikan sebuat pemikiran dan wawasan yang luas, saling bertukar pikiran melalui pertunjukan Didong. Sehingga tercapailah kesetaraan secara menyeluruh mengenai kepercayaan diri, kekuatan ekonomi dan akses menuju masyarakat Gayo secara keseluruhan.

Semua kebudayaan kecuali yang paling primitif secara internal bersifat majemuk dan mencerminkan sebuah percakapan berkelanjutan antara tradisi dan rangkaian gagasan mereka yang berbeda-beda (Parekh, 2008:442). Perbedaan-perbedaan dari pihak lain akan membuka wawasan kita, memecah kemajemukan internal masing-masing kebudayaan. Dalam hal ini kegunaan Didong Jalu sebagai sarana untuk mengkapanyekan pemilihan pemerintahan. Hal tersebut dilakukan untuk memberikan pendapat (terlepas dari positif dan negative) tentang calon yang akan dipilih. Dalam pertunjukan Didong Jalu, setiap kelompok akan saling mengadu pantun, prosa dan liriknya juga berisikan pesan atau pujian untuk calon pemimpin daerah. Namun dampak yang paling negative dari pertunjukan ini adalah kurangnya estetika masyarakat untuk melihat pertunjukan itu. Jika apa yang dimaksudkan malah dianggap lain bagi masyarakat atau pasangan dari calon yang akan menciptakan perseteruan, dan hal ini jelas menyalahi system multikultural. Seharusnya dengan adanya pertunjukan tersebut masyarakat dapat melihat ciri-ciri pemimpin yang baik untuk memimpin, bukan sebaliknya, memilih pemimpin dari hasil pertunjukan yang menjelek-jelekkan pemimpin yang lain. Namun sekarang hal ini sudah jarang dilakukan, mengingat beberapa kejadian yang tidak menguntungkan. Bukan hanya dalam sarana pemilihan, pada perlombaan juga pernah terjadi kesalah pahaman estetika pertunjukan. Seharusnya kita sebagai masyarakat yang pluralistik dapat mengapresiasi hal tersebut, karena apa? Banyak kalangan muda yang sudah tidak mau melakukan pertunjukan Didong Jalu. Mungkin hal tesebut dikarenakan efek yang ditimbukan setelah melakukan pertunjukan berdampak negative kemasyarakat.

Sekarang paradigma tentang pertunjukan Didong Jalu oleh pemuda adalah tentang siapa yang menang, asusmsinya bisa apa saja, menang karena kelompok yang lain kehabisan akal untuk "meladeni" pantun yang berisikan sindiran-sindiran halus, walaupun itu sudah meliputi aspek penilaian tentang seberapa bagus lagu yang dibuat, seberapa bagus variasi tepokan pada grup tersebut, semangat dan kekompakannya. Inilah yang membuat masyarakat multikultur sulit untuk ditata, mereka tidak perlu mengalami mimpi buruk politis dan bahkan mungkin bisa menyenangkan jika kita menghilangkan kekhawatiran tradisional kita yang panjang dengan suatu pemerintahan yang homogen secara kultural dan struktur dengan ketat, dan bukannya membiarkan masyarakat tersebut menganut bentuk-bentuk kelembagaan, bentuk pemerintahan, serta keutamaankeutamaan politik dan moral milik mereka yang pantas (Parekh, 2008:450). Mereka perlu menemukan cara-cara menggabungkan tuntutan yang sah mengenai kesatuan dan keanekaragaman pemahaman estetika tentang Didong dan Didong Jalu, menjunjung tinggi nilai budaya yang ada agar hasil dari kebudayaan ini tidak hilang dari waktu ke waktu.

\section{PENUTUP}

Kebudayaan tersebut merupakan hasil kebiasaan masyarakat, dalam hal ini berupa pemikiran-pemikiran, karya seni sampai pada bentuk bahasa. Kemudian bentuk dari kebudaan itu bertahan sampai sekarang, melalui proses pembelajaran. Oleh karena itu, tradisi selain di temukan juga diciptakan. Dengan demikian bentuk kebudayaan (dalam hal ini seni pertunjukan tradisional) dapat dipahami sebagai kegiatan seni pertunjukan yang memuat nilai dan makna pemikiran, kebiasaan, kepercayaan, norma, adat istiadat untuk diwariskan dari generasi ke generasi.

Khususnya seni pertunjukan Didong, sebagai hasil dari kebudayaan Gayo, Didong berperan besar dalam mempersatukan etnis Gayo yang memiliki berbagai macam 
pendapat mengenai nilai-nilai moral dan estetika tentang budaya yang ada. Tentu saja sebagai media pembelajaran, khususnya dalam ranah pendidikan karakter dengan pendekatan nilai, Didong merupakan kesenian yang tepat. Hampir semua kesenian daerah memiliki esensi yang tinggi, yang dapat digunakan sebagai media seni dalam pendidikan karakter. Itu semua bergantung pada apa, siapa, dan bagaiman hal tersebut diterapkan. Masyarakat Gayo harus menyatukan paradigma tentang seni pertunjukan Didong dan Didong Jalu sebagai identitas budaya daerah. Dalam persepektif multikulturalisme, Didong merupakan sebuah sarana untuk menyatukan seluruh etnis yang ada di daerah Gayo, bukan sebaliknya. Didong tidak diklaim sebagai kepemilikan setiap daerah melainkan kepemilikan bersama. Harus dapat meyatukan pemahaman estetika tentang apa yang ada dalam pertunjukan Didong secara keseluruhan, sehingga tidak terjadi kesalah pahaman yang dapat merusak nilai seni dari Didong itu sendiri.

\section{DAFTAR PUSTAKA}

Algayoni, Yusradi Usman. 2015. "Pelestarian Bahasa Gayo”. Jurnal: Serambi Indonesia 2015.

Darmawan, 2010. "Peranan Sarak Opat Dalam Masyarakat Gayo”. Jurnal: Kanun No.50 Edisi April 2010.

Dalmeri, "Pendidikan Untuk Pengembangan Karakter, Telaah terhadap Gagasan Thomas Lickona dalam Educating for Character", Jurnal Al-Ulum IAIN Sultan Amai Gorontalo. Volume 14, Nomor 14 (Juni 2014), 278.

Haviland, Wiliam A. 1988. "Antropologi:

Jilid 2". Jakarta : Erlangga.

Koentjaraningrat. 2009. "Pengantar Ilmu

Antropologi". Rineka Cipta.

Lickona dalam Educating for

Character", Jurnal Al-Ulum IAIN

Sultan Amai Gorontalo. Volume 14, Nomor 14 (Juni 2014), 278.

Lickona, Thomas. Educating for Character, Mendidik Untuk Membentuk Karakter. terjemahan Juma Abdu Wamaungo. Jakarta: Bumi Aksara, 2013.

Lickona, Thomas. Pendidikan Karakter. terjemahan Saut Pasaribu. Jakarta: Bumi Aksara, 2013.
Lickona, Thomas. 11 Principles of Character Education, Character.org., 6, melalui http://www.character.org/uploa ds/PDFs/ElevenPrinciples_new2010.pd f[21/01/2015], 2010.

Melalatoa, M. Junus. 2001. "Didong Pentas Kreativitas Gayo”. Jakarta. Yayasan Obor Indonesia

Merriam, Alan P. 2000. “Antropologi Musik(Terjemahan)". Universitas Negeri Semarang. Semarang. 2000.

Hidayat, Asep Saeful. "Manajemen Sekolah Berbasis Karakter", Jurnal Inovasi dan Kewirausahaan. Volume 1, No. 1 (Januari 2012), 9.

Parekh, Bikhu. 2008. "Rethingking Multikulturalisme, Keberagaman Budaya Dan Teori Politik". Yogyakarta : Impulse dan Kanisius. Syam, Nur. 2009. "Tantangan Multikulturalisme Indonesia". Yogyakarta : Impulse Dan Kanisius. Triyanto. 2017. "Spirit Ideologis Pendidikan Seni”. Semarang: Cipta Prima Nusantara.

\section{Webtografy}

http://lintasgayo.co/2015/09/18/buku-tradisilisan-didong-karya-isma-tantawisegera-terbit.

https://uwein.wordpress.com/2008/07/30/perta rungan-didong-jalu/ 